Саша С. Чорболоковић

ОШ „З. октобар" Бор

Универзитет у Београду

Филолошки факултет
UDC: $371.3:: 811.163 .41 ' 35]: 004.738 .5$

DOI: $10.18485 /$ dh.2015.2.ch8

\title{
ДИГИТАЛНА ФОТОГРАФИЈА У НАСТАВИ ПРАВОПИСА
}

\section{Сажетак}

Предмет овог рада су дигиталне фотографије јавних натписа са неком правописном грешком. Основни циљ рада је разматрање могућности њихове употребе као визуелног наставног средства у настави правописа. Задаци рада су представљање конкретних начина употребе дигиталних фотографија у настави правописа, као и утврђивање колико се оваквим начином организовања наставног процеса успоставља добра међупредметна и унутарпредметна корелација, каква је мотивисаност ученика, да ли се побољшава степен усвојености градива и сл. Путем дигиталне фотографије, градиво постаје занимљивије и привлачније за учење, ученици лакше уочавају бројне неправилности, своје знање активно примењују повезивањем градива са примерима правописних огрешења из непосредног окружења. Учењем на препознатим грешкама развија се и критичко и логичко мишљење, подиже се свест о важности примене правописа, нарочито у јавном простору, а сама настава правописа има одлике истраживачке, проблемске, игролике и стваралачке наставе.

Кључне речи: правописна грешка, натпис, фотографија, методика наставе, српски језик.

\section{1. Увод}

Један од примарних програмских задатака наставе српског језика је поступно и систематично упознавање ученика са ортографском нормом српског језика, тј. њихово описмењавање на темељима ортографских стандарда. Нажалост, наставна пракса показује недопустиве грешке, неизграђену навику правилног писања. ${ }^{1}$

1 „Пошто се писменост првенствено везује за наставу српског језика и књижевности, наставници нејезичких предмета сматрају да нису задужени за ову наставну област, 
Садашња настава правописа се, с друге стране, углавном заснива на учењу, препознавању и увежбавању нормативних правила путем правописних вежби. Примери су често неактуелни и ученицима незанимљиви, а осим тога и неповезани са језичком праксом услед чега ученици имају пасивно знање правописа.

Будући да су дигиталне технологије фотографисање учиниле компулзивном делатношћу, актуелност дигиталне фотографије се може (и мора) искористити и у наставном процесу у циљу његовог осавремењивања.

Предмет овог рада су дигиталне фотографије јавних натписа са неком правописном грешком. Основни циљ рада је испитивање могућности њиховог коришћења као визуелног наставног средства у настави правописа. Задаци рада су представљање конкретних начина употребе дигиталних фотографија у настави правописа, као и утврђивање колико се оваквим начином организовања наставног процеса успоставља добра међупредметна и унутарпредметна корелација, какав је степен усвојености градива, каква је мотивисаност ученика и сл.

\section{2. Фотографија у методичкој литератури}

Методичка литература аналогну фотографију углавном помиње као једно од визуелних наставних средстава, наставних средстава са посредничком улогом (Тежак „Граматика” 105; Росандић „Методика” 287; Николић „Методика” 63; Илић „Српски језик” 106; Павловић „Припремање наставника" 184), и то у оквиру методе демонстрације (методе запажања и показивања) и принципа очигледности. При свему томе, аутори нису терминолошки јединствени. Највећи број њих фотографију изједначава са сликом. Има оних који слику узимају као надређени термин наводећи да се слике деле на фотографске и

што директно утиче на то да ученицима недостају узори међу наставницима од којих могу учити ваљано усмено и писмено изражавање" (Тривић, Стевановић 166). Сходно томе, не чуди залагање многих лингвиста да правопис као предмет (савладавање језичке писмености) буде обавезан на сваком факултету, а посебно на оним који припремају студенте за наставнички позив јер је мало вероватно да ће неко бити успешан у давању доброг примера језичке писмености ако за то није оспособљен. 
уметничке 2 или пак фотографије сврстава у неуметничке илустрације. Међутим, већина се слаже у томе да је улога фотографије у настави вишеструка: њоме се развија мотивација, стимулише перцепција и мисаона активност субјеката наставе. Петровачки, Штасни („Методичке апликације" 348) истичу да фотографија може допринети различитим пожељним образовним ефектима, као илустрација за појмове и објекте, који ђацима нису искуствено познати. Зато се може рећи да фотографија има мотивациону, илустративну, пропратну или сазнајну улогу. Она има примену у свим подобластима предмета Српски језик: у настави књижевности (фотографије књижевника, уметничке слике, факсимил рукописа...), у настави језика (фотографије заслужних људи за развој језика, језичких споменика), али и у језичкој култури (фотографија као основа одређене говорне вежбе). Углавном се помињу фотографије које наставник тражи, припрема за час, говори се о његовој личној фототеци, али се ретко кад препоручује ангажовање ученика на прикупљању тог визуелног наставног садржаја („Дружине” 77). Зиндовић-Вукадиновић („Слика у настави и учењу” 126-129) говори о историјату слике и њеној улози у настави наглашавајући да њена улога у васпитно-образовном процесу важна, али да је не треба прецењивати. Она мора бити дозирана, брижљиво одабрана и функционално употребљена. Витич, Шулер („Аудио-визуелна средства” 59-85) доносе најдетаљнији приказ фотографије од општих карактеристика, важности, приступачности и ефикасности овог наставног средства до монтирања и предлога коришћења слика у настави.

\section{3. Могућности примене дигиталне фотографије у настави правописа}

Како би настава правописа постала више практично употребљива, очигледнија, ближа и атрактивнија за учење, она мора бити мултидисциплинарна јер техничко-технолошке иновације повлаче за собом и бројне иновације у самом раду наставника, али и на-

2 РСЈ у оквиру примарног значења полисемичне одреднице слика, поред „уметнички приказ бојом и цртежом на равној подлози (платну, хартији исл.) онога што постоји у стварности или машти (1.а)“, наводи и „фотографија“ (1.б). 
чину организовања наставе. Компјутери у настави нису више питање избора већ неминовност, баш као што сваки наставник поред оспособљености да предаје свој предмет, мора поседовати и одређено компјутерско знање.

Један од могућих начина иновирања наставе правописа, повезивања традиционалне и дигиталне писмености може се постићи прикупљањем фотографија јавних натписа са неком правописном грешком и њиховим слањем путем електронске поште. На овај начин, спаја се актуелност фотографије и настава правописа, вербални и визуелни елемент (фотографија правописних огрешења појачава уверљивост правописних правила), остварује се међупредметна корелација Српског језика и Информатике (пребацивање фотографија, њихова обрада и слање путем електронске поште).

Дигиталне фотографије у настави правописа могу бити вишефункционалне. Неке од могућности употребе у настави су: наставна изложба, тематски албум (филолошка шетња), језичка игра, основа за састављање питања, пример уз лекцију.

\section{1. Наставна изложба}

Витич, Шулер („Аудио-визуелна средства” 136) истичу да наставна изложба треба да буде резултат заједничког планирања наставника и ученика. Она треба да одражава максимум ученичке иницијативе и стваралачког учешћа. Једна од таквих изложби је и изложба фотографија јавних натписа са правописном грешком. Оваква изложба привлачи ученике и побуђује мотивацију. Она је у исто време и мотивациона, али и развојна јер пружа могућности за развијање одговорности и свести о важности поштовања правописа нарочито у јавном простору. У њеној припреми и реализацији има више фаза:

1. Расписивање фото-конкурса;

2. Фотографисање и слање примера електронском поштом;

3. Прегледање и анализа примера;

4. Заједнички задаци на припреми изложбе (план изложбе);

5. Уређивање изложбе;

6. Завршна наставна изложба (проглашење победника конкурса). 


\section{Пример фото-изложбе Ма ко је бре неписмен!}

Прва фаза наставне изложбе био је фото-конкурс путем кога је прикупљено 95 фотографија јавних натписа са правописном грешком. На конкурсу су учествовале све борске основне школе. У другој фази грешке су анализиране и груписане по правописним областима (велико слово, писмо, интерпункција и транскрипција). У оквиру заједничких задатака на припреми изложбе прво је одређен наслов Ма ко је бре неписмен у коме је садржана основна идеја да правила без примене немају никакву вредност и важност, а потом се приступило визуелном представљању теме. Написане су кратке духовите дијалошке ситуације у вези са правописним темама у којима су регистроване најчешће грешке, извршен је избор глумаца, чланова драмске секције, који су добили задатак да науче (драматизују) текст, и на крају су снимљени и кратки видео записи. Једна група ученика је изабрала мисли наших лингвиста о језику, које су прекуцане и убачене у посебно декорисане рамове. Чланови ликовне секције су осмислили граничнике за књиге са правописним правилима и мале коверте са по једним правописним правилом, које су посетиоци добили на изложби. Изабрани су и лапсуси и досетке ученика у вези са правописом, које су потом ученици обликовали у виду кратких стрипова. Финална фаза била је фото-изложба у борској Народној библиотеци, на којој су били проглашени победници конкурса.

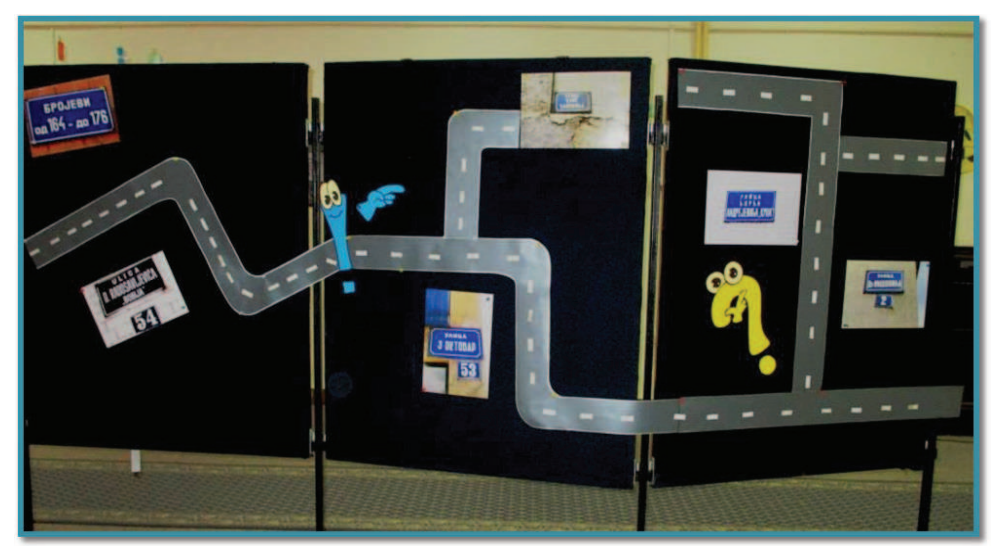

Слика 1: Део изложбе (називи улица и тргова) 


\section{2. Филолошка шетња}

Дигиталне фотографије се могу прикупљати у оквиру филолошке шетње градом³, где би ученици обиласком улица или насеља у граду требало да уоче, а потом и фотографишу мобилним телефоном или дигиталним фото-апаратом неправилне јавне натписе.

Најбоље је ученике поделити у неколико група и дати им посебне задатке: једна група ће фотографисати само натписе улица и тргова, друга ће се бавити само називима фирми, трећа ће истраживати само правописне грешке на плакатима и у огласима, четврта ће пажњу усмерити само на знакове саобраћајних раскрсница и сл.

Наставник може дати и неке мале смернице у виду назнака и препорука које делове града би требало посетити и истражити како би задаци били што брже и успешније урађени. Задаци сваке филолошке шетње обавезно се морају добро осмислити и временски ограничити.

Такође, наставник мора бити спреман на различите усликане примере, од којих неће сви бити неправилни јер постоји више допуштених правописних решења које ученици не знају или се врло често колебају око тога шта је правилно, а шта неправилно (нарочито у огласима и на плакатима). Након прикупљања примера, приступа се њиховом сређивању, смишљању коментара за презентацију (правописни фото-албум), која се реализује на посебном часу. Ученичка креативност и оригиналност може се јасно уочити у начину презентације (обичне или мултимедијалне).

\section{Пример филолошке шетње}

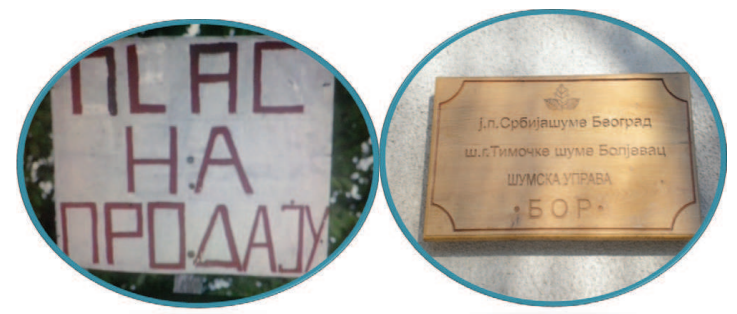

Слика 2: Писмо

3 Детаљније о филошкој шетњи говори и Чорболоковић („Правописни квиз”). 


\section{3. Основа питања}

Фотографије натписа са правописним грешкама представљају добар материјал за састављање питања различитог типа и тежине. Са̂м метод постављања питања се ипак прилагођава ограниченом броју примера. Приликом њиховог формулисања мора се водити рачуна да она буду примерена различитим ученичким могућностима, прилагођена узрасту и направљена према постојећим образовним стандардима. Може се користити један натпис или више њих са истим типом грешке, или више варијанти једног натписа. У том случају питањима је обухваћена само по једна правописна област. Друга могућност подразумева натписе са више грешака. Тада би се проверавало познавање једне правописне области или више њих. Натпис може бити основа за једно питање, али и два или више, све у зависности од идеје наставника, потребе наставне јединице и типа часа.

Нека од ових питања личе на постојећа текстуална питања (вишеструки избор) у нашим радним свескама и збиркама задатака, са једином разликом што се уместо понуђених одговора јављају варијанте једног или више различитих натписа. У другима је натпис само полазна основа, после које следи радни захтев. Са̂м радни захтев је тако формулисан да се од ученика очекује да суштински разуме градиво, да уме логички да размишља и повезује и да научено градиво из правописа активно примењује. Ова питања налик су на нелинерни тип текста (Чорболоковић „Јавни натписи са грешком").

\section{Пример питања на наставном листићу или у квизу:}

Црта се употребљава у значењу ОД ДО. Пронађи натпис у коме је она правилно употребљена и упиши знак $\vee$ у одговарајућу кућицу: 

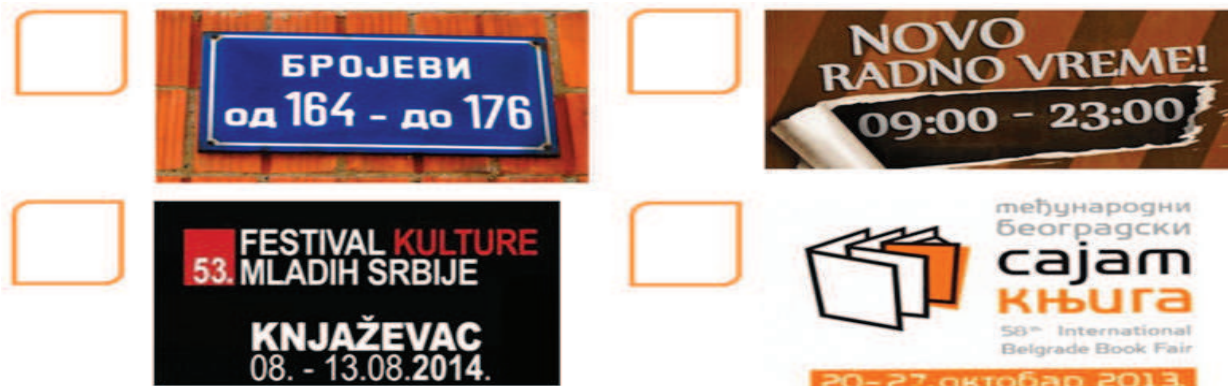

meђународни

cajern 08. -13.08 .2014$

Слика 3: Интерпункција

Међу понуђеним натписима пронађи оне у којима постоји грешка у писању школске године. Заокружи слова испред таквих натписа.
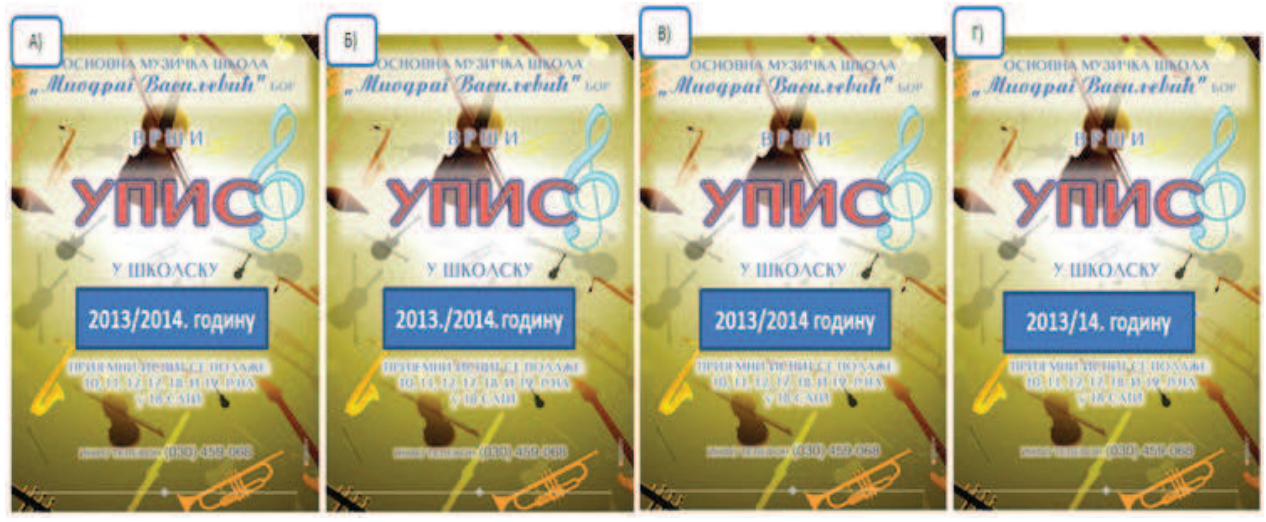

Слика 4: Интерпункција

\section{4. Пример уз лекцију}

Приликом обраде одређене наставне јединице из правописа уз уобичајене примере могу се и навести неки примери правописних огрешења што ће битно утицати на побошање ученичког знања правописа. Повезивањем градива са реалним и њима блиским ситуацијама, ученици ће лакше уочавати недопустиве правописне грешке у окружењу, а спречиће се или смањити илустрациони формализам у настави. 


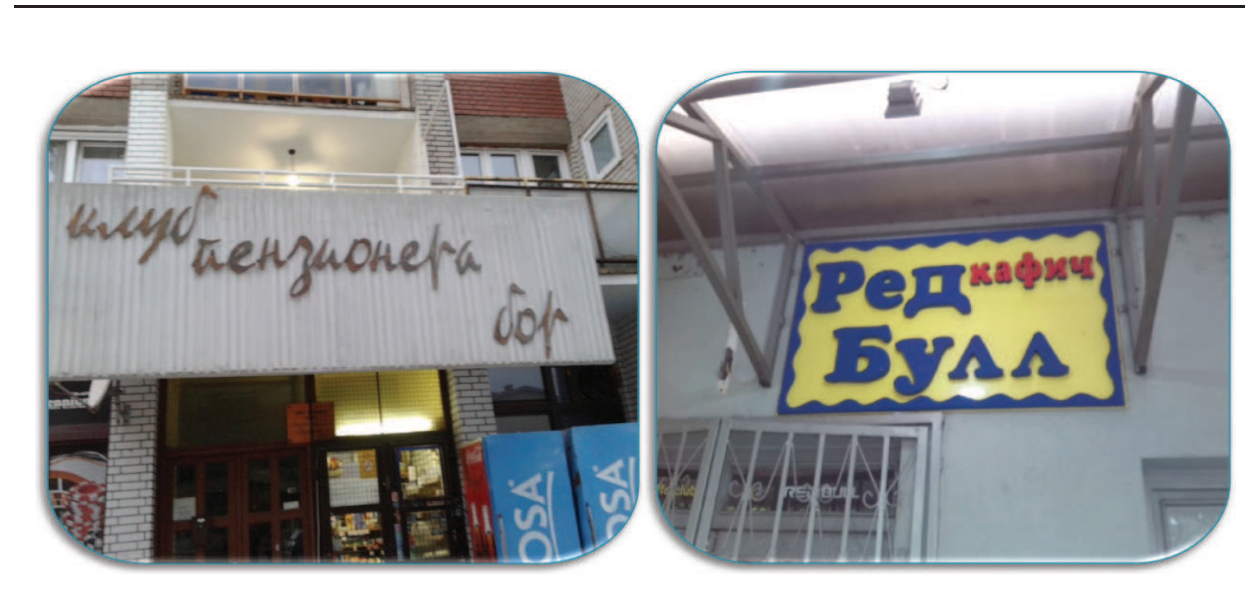

Слика 5: Велико слово и транскрипција

Први пример је погодан приликом обраде назива институција, организација, радњи, а други каодобар примерза лошутранскрипцију (прилагођено писање страних речи) и мешање сугласника Ч и Ћ. Дати примери ће појачати уверљивост правила, дакле, визуелни елемент ће употпунити вербални, и допринесе хармоничном прожимању.

\section{5. Језичке игре}

Дигитална фотографија може бити и део одређене језичке игре: пронађи грешку или тачно/нетачно. Прва игра се може повезати са информатичким знањем јер је могуће захтевати не само уочавање, објашњење грешке, него и у одређеном програму за обраду фотографије и њено исправљање. За овако организоване часове, погодније су фотографије са више правописних огрешења. За игру тачно/нетачно 4 могу се помешати фотографије са грешкама и без грешака (ПП презентација), примери норме и огрешења о норму, услед чега би ученици проверили своје знање. Тако правописна правила постају јаснија, а настава, услед игровне активности, интересантнија, а сами ученици имају прецизнију и реалнију слику о сопственом знању.

4 У овој игри учесвовао би по један представник групе. У петом и шестом разреду у циљу постизања динамичности и занимљивости ове игре могуће је на две столице поставити натписе тачно и нетачно, где после сваке фотографије у ПП презентацији ученици треба да седну на једну од столица у зависности од процене изнесене тврдње (в. шире у: Чорболоковић, „Правописни квиз”). 


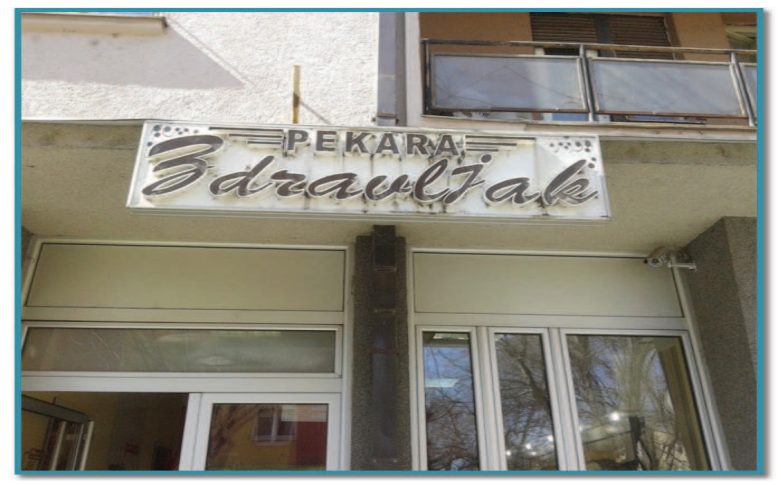

Слика 6: Писмо

\section{4. Закључне напомене}

У раду су приказане неке од могућности коришћења дигиталних фотографија јавних натписа са правописном грешком: наставна изложба, филолошка шетња, питање, пример уз лекцију, језичка игра.

Наставна изложба и филолошка шетња подразумевају активну потрагу ученика за правописним грешкама док се игра и примери уз лекцију ослањају на наставникову прикупљену и архивирану збирку/ фототеку. Без обзира на начин прикупљања и коришћења дигиталних фотографија у настави правописа, оваквим иновативним приступом развија се радозналост и жеља за учењем (унапређује се учење), за активним учествовањем у наставном процесу, повећава се квалитет комуникације између наставника и ученика, а ученици боље разумеју везу и односе између онога што уче и реалног окружења (правописних огрешења).

Учењем на препознатим грешкама развија се и критичко и логичко мишљење, подиже се свест о важности примене правописа, нарочито у јавном простору.

Ученици се оспособљавају за рад у информацијском друштву, постају самостални, добро организовани, предузимљиви са стеченим функционалним знањем.

Путем дигиталне фотографије као визуелног наставног средства, градиво постаје занимљивије и привлачније за учење, а сама наста- 
ва правописа добија одлике истраживачке, проблемске, игролике и стваралачке наставе. Такође, она је и интегративна јер повезује знања из различитих предмета: Информатике, Ликовне културе и Српског језика (међупредметна корелација) у складу са захтевима савремене методике наставе, а која обједињује учење откривањем, решавање проблема и креативне активности.

\section{Литература}

Витич, Волтер Арно и Шулер, Чарлс Франсис. Аудио-визуелна средства. Београд: Вук Караџић, 1966.

Илић, Павле. Српски језик и књижевност у наставној теорији и пракси. Нови Сад: Змај, 2006.

Зиндовић-Вукадиновић 1985: Гордана Зиндовић Вукадиновић. „Слика у настави и учењу", Иновације у настави, бр. 2, 125-129.

Николић, Милија. Методика наставе српског језика и књижевности. Београд: Завод за уџбенике и наставна средства, 2006.

Павловић, Миодраг. Припремање наставника и ученика за тумачење књижевних дела. Београд: Завод за уџбенике, 2008.

Петровачки, Љиљана и Штасни, Гордана. Методичке апликације. Нови Сад: Филозофски факултет, 2008.

Росандић, Драгутин. Методика књижевног одгоја и образовања. Загреб: Школска књига, 1986.

PCJ: Речник српског језика, Нови Сад: Матица српска.

Тежак, Стјепко. Литерарне, новинарске, рецитаторске и сродне дружине. Загреб: Школска књига, 1969.

Тежак, Стјепко. Граматика у основној школи. Загреб: Школска књига, 1980.

Тривић, Драгица и Стевановић, Јелена. „Језичка и научна писменост: предуслов за ефикасно учење". Стваралашро, иницијатива и сарадња (импликације за образовну праксу), други део (приредиле Јасмина Шефер и Јелена Радишић). Београд: Институт за педагошка истраживања (2012): 159-185.

Чорболоковић, Саша. „Правописни квиз у осмом разреду”. Методички видици 4. (2013): 107-119.

Чорболоковић, Саша. „Јавни натписи са грешкама у настави правописа у основној школи (од 5. до 8. разреда)". Зборник са научног скупа Имплементација иновација у образовању и васпитању - изазови и дилеме. Учитељски факултет: Београд (2015): 457-471. 


\author{
Saša Čorbolaković \\ Primary School "3. oktobar", Bor \\ University of Belgrade \\ Faculty of Philology
}

\title{
DIGITAL PHOTOGRAPH AS THE MEANS OF SPELLING TEACHING
}

\begin{abstract}
Summary
Modern spelling teaching has to take the use of spelling rules into consideration more than it used to and has to be more catching for today students, closer to their needs and interests. This research work deals with the possibilities of the use of a digital photograph as the means of spelling teaching, being present and wide- spread so much among students in the recent years ( almost there's not a single student who hasn't taken at least a photo using his phone more often than camera). The im mediate subject of this work is the methodical and educational use of the digital photographs of the public inscriptions containing a certain spelling mistake. "Who, the hell, is illiterate?" programme serves as an example. The photo prize competition is its first phase. Ninety-five photographs of the public inscriptions with a spelling mistake have been collected. The following phases are: grouping the examples according to the spelling topic, mistake analysis and recording short funny videos relating to those spelling topics with the most frequent mistakes. The photo exhibition is the final phase, and it can also be used as a good demonstration lesson. The aims of this work are presentation of the examples' most common spelling mistakes, their classification according to the spelling topics, and their illustration by writing short funny dialogues. Another aim is the analysis of the students being motivated and active while looking for those mistakes. This work also tries to find out how good correlation among subjects ( Serbian language, ICT, Art, etc.) and within a subject ( literature, spelling) can be established when organizing a teaching process this way. When using a digital photograph ( taking photos and sending them by email) as the visual means of teaching, the subject matter is expected to be more interesting and catching for a learner. Students are also expected to notice irregularities easier, and to apply their knowledge actively by connecting the subject matter to the immediate surrounding spelling mistake examples. Learning process when mistakes are noticed and recognized develops both critical and logical thinking, raises the awareness hoe spelling is important, especially in public. This is how spelling teaching starts getting the characteristics of being researching, problem solving, playlike and creative.
\end{abstract}

Key words: teaching, spelling mistake, public, inscription, photograph, methodics, Serbian language 